\title{
A Game-Theoretical Interpretation of Inflation and Unemployment in Western Europe*
}

\author{
FRITZ W. SCHAR PF Max-Planck-Institut für Gesellschaftsforschung, \\ Cologne
}

\section{ABSTRACT}

The paper aims at a more complete, yet still parsimonious, explanation of macro-economic policy failure and success during the 'stagflation' period of the I970s. Focusing on four countries, Austria, Great Britain, Sweden and West Germany, it is shown that both runaway inflation and rising unemployment could be avoided whenever it was possible to achieve a Keynesian concertation between fiscal and monetary expansion on the one hand and union wage restraint on the other. The actual policy experiences of the four countries are then explained in terms of the linkage between a 'coordination game' played between the government and the unions in which macro-economic outcomes are determined, and a politics game in which the government tries to anticipate the electoral responses of different voter strata to these outcomes.

Political scientists and economists with a comparative bent have been fascinated by the opportunities for theory testing and theory building provided by the large-scale 'natural experiment' of the worldwide economic crisis that began in the early I 970 . Compared to the preceding decade, the middle and late 1970 os and the early 1980 s were indeed a difficult period for all industrialized Western (OECD) countries. Economic growth and employment growth were reduced by half, while rates of unemployment and inflation levels were on the average twice as high. (Table 1 ). But even as the average economic and employment performance of OECD countries declined after 1973, the relative distance

\footnotetext{
* The paper is based on a book length study (Scharpf, 1987b) that was completed while I was working at the Labor Market Policy Research Unit of the Wissenschaftszentrum Berlin. Earlier versions have profited from seminar discussions at the Center for Advanced Study in the Behavioral Sciences, Stanford, at the Workshop in Political Theory and Policy Analysis, Indiana University, at the Center for European Studies, Harvard University, and at the School of Business and Public Administration, California State University, San Bernardino. I have also profited from the helpful comments of Jens Alber, Jürgen Feick, Bernd Marin, Renate Mayntz, Manfred Schmidt and Douglas Webber.
} 
TA B LE I: Changes In OECD Economies, $1963-83$

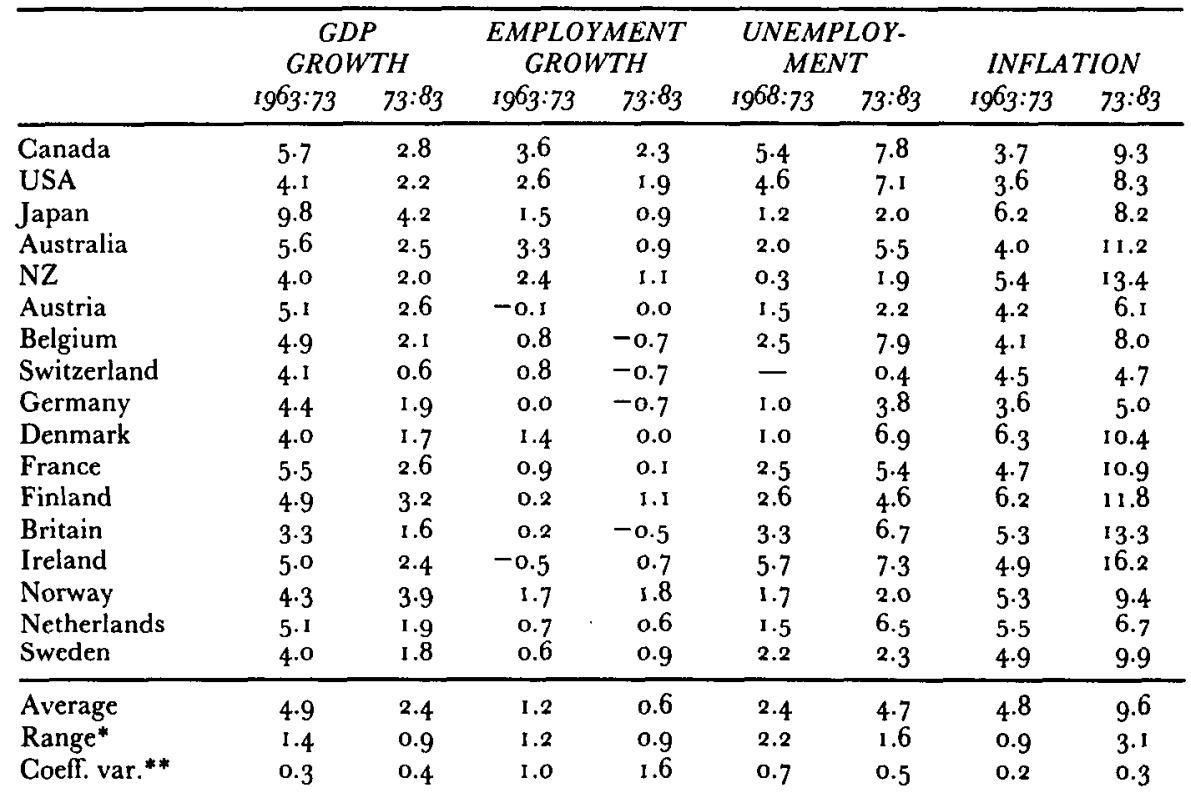

* Relative Range $=($ Maximum-Minimum $) /$ Average.

** Coefficient of Variability=Standard Deviation/Average.

Source: OECD Historical Statistics I $960-1984$.

between more and less successful countries increased considerably for most indicators of economic performance. Equally interesting is the fact that cross-national differences do not seem to correspond to conventional economic hypotheses (Therborn, 1986). Even the almost tautological link between economic growth and employment is weak $\left(\mathrm{R}^{2}=0.32\right)$. There is no statistical association between employment growth and levels of unemployment, which are affected not only by the course of the economy but also by changes of the supply of labor $\left(R^{2}=0.01\right)$. The relations between economic growth and inflation $\left(R^{2}=0.02\right)$ and employment growth and inflation $\left(R^{2}=0.07\right)$ are also extremely weak.

Similarly, a scatterplot of the two indicators with the greatest political salience, inflation and unemployment, does not confirm expectations associated with the once-popular Phillips curve of a strongly negative correlation. The correlation is instead weakly positive, and there have been countries with low and others with high rates of inflation at every level of unemployment (Figure I). Confronted with the worldwide crisis, OECD countries apparently have achieved widely differing profiles of economic performance, some reaching a compromise among several goals, some doing poorly in most respects, and some doing well in one dimension and poorly in another.

Political scientists have been attracted by this body of economically 
Inflation $1973^{-83}$

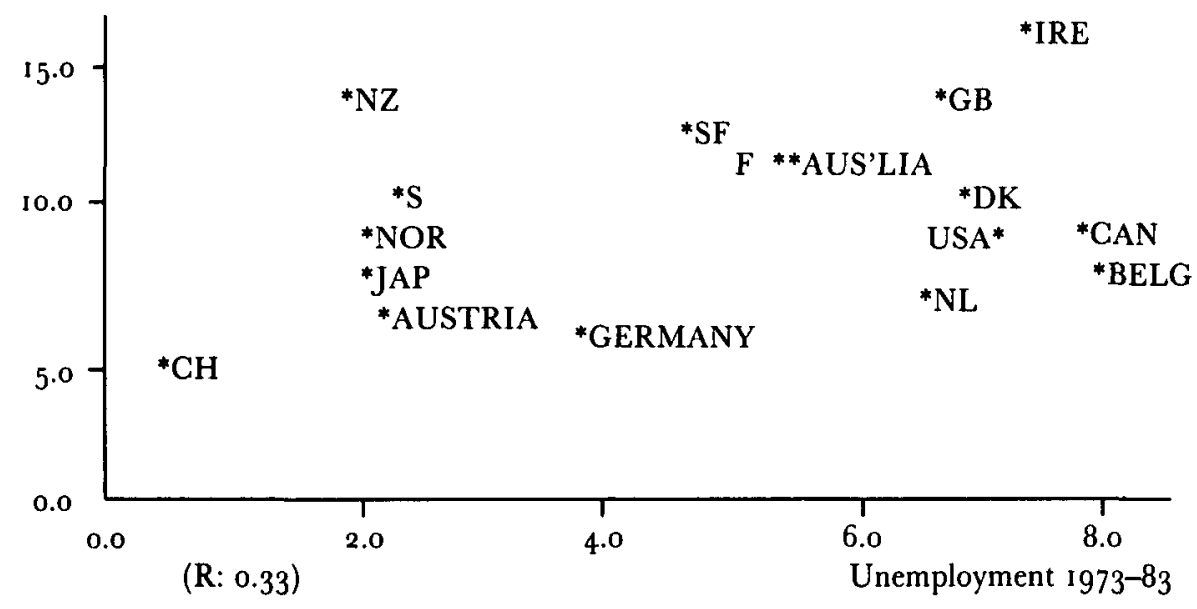

FIG URE I: Inflation and Unemployment in OECD Countries 1973-83

unexplained variance. Cross-national quantitative studies, focusing on the party-political orientation of national governments, were initially able to show that left-of-center governments were associated with lower rates of unemployment and higher rates of inflation than conservative governments (Hibbs, 1977). When that relationship, which had been established for the 1960 , did not hold up in the I97os, the focus shifted to tripartite institutional arrangements linking the state with the peak associations of capital and labor, whose relevance for the general 'governability' of countries had been postulated by Philippe Schmitter's (1974; 198I) theory of neo-corporatism. In particular, it could be shown in a considerable number of studies using a variety of indicators that, by and large, countries with powerful, organisationally concentrated and centralized labor movements and left-of-center governments had done relatively well in economic terms during the 1970s (Cameron, 1978; 1984; Schmidt, 1982; 1983; Paloheimo, 1984; Lange and Garrett, 1985).

But once again the explanations that were successful in one decade did not survive far into the next. Some of the model countries got into trouble in the I 1980 , and other countries that were clearly not dominated by parties of the left and in which organized labor was weak and fragmented, were doing relatively well. In response, the corporatist model was revised to emphasize the functional equivalence of labor-dominated concertations between organized economic interests and the state, and of Japanese or Swiss-style 'corporatism without labor' (Schmidt, I986; Garrett and Lange, I986; Wilensky and Turner, 1987).

On the whole, it seems fair to say that these cross-national political 
science studies have not yet converged upon an explanatory model that is stable over time and theoretically well-grounded (Therborn, 1986). It is also easy to identify the reasons for these deficiencies. Governments of differing political complexion may indeed have specific political preferences, but their ability to translate these into effective public policy is institutionally constrained, and the outcomes of effective public policy are crucially dependent upon changing economic circumstances. Thus, the extension of explanatory models to include neo-corporatist institutional arrangements was a step in the right direction which did not go far enough. However difficult, we must try to disentangle the interaction between changes in the economic environment, the economic strategy choices available to national policy makers, and the institutional conditions facilitating and constraining such choices, if we hope to develop explanations of economic performance that are not so easily upset by the mere passage of time (Scharpf, 1984; Hall, 1986; Martin, 1986a). In the present paper I will try to develop a more comprehensive, yet still relatively parsimonious explanatory model of the macro-economic policy choices of Western European countries during the I 970 os and early ig8os.

\section{The Puzzle}

In the spirit of the most similar case approach (Przeworski and Teune, 1970), the following analysis is based on comparative studies of the economic and employment policies pursued by four Western European countries, Austria, Great Britain, Sweden, and West Germany (Scharpf, I $98 \mathrm{I} ; 1984 ; 1987 \mathrm{~b})$. All of them were governed in the first critical years after 1973 by Socialist, Social Democratic or Labour parties that had a clear political commitment to maintaining full employment. Furthermore, on the eve of the crisis all four countries found themselves in rather similar, and on the whole quite comfortable, economic circumstances. Britain, in particular, had not looked like the sick man of Europe in 1973 , achieving the highest rate of economic growth $(7.6 \%)$ and doing relatively well on inflation. By comparison, Austria and Sweden (with growth rates of $4.9 \%$ and $4.0 \%$ respectively) might have had more reason to be worried about their relative performance. Yet immediately after the onset of the crisis in the fall of I 973 , the four countries began to move apart economically.

Between 1974 and 1979 , when the Labour party left office, Britain became the worst case of the four, with the lowest rate of average economic growth ( $1.5 \%$ ), by far the highest rate of inflation $(\mathrm{I} 6 \%)$, and the highest unemployment $(\mathbf{5 . 0} \%)$ as well. By contrast, Austria now had the best all-round record, with the highest economic growth $(2.9 \%)$, the second-lowest inflation (6.0\%) and the lowest unemployment (г.8\%). 
Even more interesting is the contrast between the two countries with intermediate performances: West Germany suffered the largest increase in unemployment compared to 1973 (from $0.8 \%$ to an average of $3.2 \%$ ) and achieved the greatest degree of price stability (4.8\%); Sweden was even able to reduce unemployment during the first five years of the crisis (from $3.0 \%$ to $1.9 \%$ ) but suffered from double-digit inflation (10.6\%) in the $1974-79$ period.

In order to explain this puzzle of widely diverging economic outcomes in the face of similar policy preferences and starting conditions, it is necessary to begin with a brief analysis of the economic environment and strategy choices of industrialized countries in the early I970s. In a nutshell, the dominant economic problem of the i 970 os was stagflation, the simultaneous occurrence of exceptionally high rates of inflation and levels of mass unemployment previously unheard of in the postwar period. In order to understand its intractability, it is useful to distinguish between causes on the demand side and on the supply side of the markets for goods and services (Malinvaud, 1977). Inflation could be either of the demand pull or the cost push variety, and unemployment could be either Keynesian (if firms were unable to sell as much as they would have liked to produce at current prices and costs) or classical (if firms did not find it profitable to produce more at current prices and costs). It was also possible that more than one type of problem was manifest at a given time (Figure 2).

In the early I 970 os the world economy had already suffered from a good deal of demand inflation, which had been initiated by the American decision to finance the Vietnam war without raising taxes. Price rises accelerated significantly, however, when the powerful cost push of a raw materials boom and of the first oil crisis was added in 1973/74. At the same time, the twelve-fold increase of the oil bill within a few months constituted a sudden transfer of purchasing power from the oil-consuming

F I U R e 2: Typology of Economic Policy Problems in the 1970 s

Source of Problem

\begin{tabular}{|c|c|c|}
\hline & Demand Side & Supply Side \\
\hline Inflation & $\begin{array}{l}\text { Demand Pull } \\
\text { Inflation }\end{array}$ & $\begin{array}{l}\text { Cost Push } \\
\text { Inflation }\end{array}$ \\
\hline Unemployment & $\begin{array}{l}\text { Demand Gap } \\
\text { (Keynesian) } \\
\text { Unemployment }\end{array}$ & $\begin{array}{l}\text { Profit Gap } \\
\text { (Classical) } \\
\text { Unemployment }\end{array}$ \\
\hline
\end{tabular}


industrial countries to the oil-exporting countries. As these were not immediately able to spend their new wealth in the international markets for goods and services, OPEC surpluses jumped from $\$ 8$ Billion in 1973 to $\$ 60$ Billion in 1974 (OECD Economic Outlook 28: 125). The immediate consequence was a demand gap of corresponding magnitude in the industrialized countries which, if it was not compensated, would generate Keynesian unemployment.

For this combination of cost-push inflation and demand-gap unemployment, national macro-economic policy makers and the prevailing practice of Keynesian demand management were ill prepared. Their major policy instruments were government fiscal policy and central bank monetary policy. ${ }^{1}$ Both could be used to reflate aggregate demand by increasing government expenditures or cutting taxes, and by increasing the money supply and lowering interest rates. Alternatively, both instruments could be used restrictively, by reducing the fiscal deficit and the money supply. As both sets of instruments affect the same parameters of aggregate demand, they needed to be employed in parallel in order to be effective. Under the conditions of stagflation, that meant that governments were able to fight either inflation or unemployment, but not both at the same time. Worse yet, in trying to solve one problem they would aggravate the other one (Figure 3 ).

The dilemma could be avoided only if economic policy makers were not limited to the use of fiscal and monetary policy, but were also able to influence wage settlements, which, although they affect aggregate demand as well, have a larger and more direct impact upon the supply side of the economy (Figure 4). Thus the inclusion of wage policy in the macro-economic tool kit greatly increased the range of problems that macro-economic policy could deal with (Weintraub, 1978).

Quite apart from the controversy about whether unions were actually responsible for the rise of inflation in the early i 970 , the direct impact of wages on the costs of production made wage restraint a highly plausible defense against the rising tide of cost-push inflation. In practical terms, that meant that the unions would need to refrain from exploiting their full

F I G U R E 3: Effects of Fiscal and Monetary Policy Under Conditions of Stagflation

\begin{tabular}{|c|c|c|}
\hline Fiscal and & $\begin{array}{l}\text { Demand Gap } \\
\text { Unemployment }\end{array}$ & $\begin{array}{c}\text { Cost Push } \\
\text { Inflation }\end{array}$ \\
\hline $\begin{array}{l}\text { Monetary Policy } \\
\text { expansionary }\end{array}$ & helps a lot & hurts \\
\hline restrictive & hurts a lot & helps \\
\hline
\end{tabular}


F I G U E 4: Effects of Wage Policy Under Conditions of Stagflation

\begin{tabular}{l|l|l|}
\multicolumn{1}{c}{} & \multicolumn{1}{c}{$\begin{array}{c}\text { Demand Gap } \\
\text { Unemployment }\end{array}$} & \multicolumn{1}{c|}{$\begin{array}{c}\text { Cost Push } \\
\text { Inflation }\end{array}$} \\
\cline { 2 - 3 } Wage Policy \\
moderate & hurts & helps a lot \\
\hline aggressive & helps & hurts a lot \\
\hline
\end{tabular}

bargaining power - which was considerable as long as the government was able to maintain full employment. In order to succeed, they would have to accept settlements which, when discounted by the increase of labor productivity, kept the rise of unit labor costs below the current rate of inflation. ${ }^{2}$ In exchange, the government was then free to use its own policy instruments to reflate aggregate demand in order to maintain full employment (Figure 5).

If that Keynesian concertation of government and union strategies was practiced, it was possible to avoid both a steep rise of unemployment and runaway inflation, even under the crisis conditions of the mid-1970s (but not in the $1980 \mathrm{~s}) .^{3}$ If, however, the unions were unwilling or unable to practice wage restraint, inflation would continue; and if the government would not reflate the economy, unemployment would increase. In actual practice, the four countries differed significantly in their ability to achieve, and maintain, a pattern of Keynesian concertation between macroeconomic policy and union wage policy.

In 1974, the immediate response of government policy to the beginning crisis was expansionary in all countries except West Germany, and even there the fiscal deficit increased as much as it did in the other three countries. The overall deflationary effect was due to the tight-money policy of the central bank. At the same time, the unions in all four

FIGURE 5: Inflation and Unemployment as Outcomes of Government and union Strategies Under Conditions of Stagflation

Fiscal and Monetary Policy expansionary

restrictive

Wage Policy

\begin{tabular}{|l|l|}
\multicolumn{1}{c}{ moderate } & aggressive \\
\hline inflation: moderate & $\begin{array}{l}\text { inflation: very high } \\
\text { unemployment: low }\end{array}$ \\
unemployment: low & inflation: high \\
inflation: low & unemployment: very high \\
unemployment: high & \\
\hline
\end{tabular}


T A B L E 2: Consumer Price Inflation and Annual Increases of Unit Labor Costs in Manufacturing

\begin{tabular}{lrrrrrrr}
\hline & $\begin{array}{c}1974 \\
\%\end{array}$ & $\begin{array}{c}1975 \\
\%\end{array}$ & $\begin{array}{c}1976 \\
\%\end{array}$ & $\begin{array}{c}1977 \\
\%\end{array}$ & $\begin{array}{c}1978 \\
\%\end{array}$ & $\begin{array}{c}1979 \\
\%\end{array}$ & $\begin{array}{c}1980 \\
\%\end{array}$ \\
\hline AUSTRIA & & & & & & & \\
Inflation & 9.5 & 8.4 & 7.3 & 5.5 & 3.6 & 3.7 & 6.4 \\
Unit L.C. & 9.7 & 15.1 & 0.5 & 5.6 & 1.2 & -1.8 & 5.9 \\
GREAT BRITAIN & & & & & & & \\
Inflation & 16.0 & 24.2 & 16.5 & 15.8 & 8.3 & 13.4 & 18.0 \\
Unit L.C. & 24.0 & 32.6 & 12.7 & 11.7 & 14.9 & 17.2 & 21.0 \\
SWEDEN & & & & & & & \\
Inflation & 9.9 & 9.8 & 10.3 & 11.4 & 10.0 & 7.2 & 13.7 \\
Unit L.C. & 12.9 & 19.3 & 16.7 & 11.1 & 8.3 & -0.1 & 9.3 \\
FR GERMANY & & & & & & & \\
Inflation & 7.0 & 6.0 & 4.5 & 3.7 & 2.7 & 4.1 & 5.5 \\
Unit L.C. & 9.1 & 6.8 & 0.6 & 5.3 & 5.0 & 2.4 & 7.3 \\
\hline
\end{tabular}

Source: OECD Historical Statistics $1960-1984$.

countries continued their more or less aggressive wage strategies. Wages contributed to accelerating inflation whenever the rise of unit labor costs (nominal wage increases minus gains in labor productivity) exceeded the current rate of inflation. As a consequence, employment was stabilized in all countries except West Germany, which suffered very large job losses in I $974-76$, but had the lowest rate of inflation of all OECD countries.

By 1976 , however, the severity of the crisis was realized, and unions had begun to moderate their wage claims in most countries, earliest in Germany and most dramatically in Britain, where inflation had exceeded 24 per cent in I975. As a consequence of the 'Social Contract' of 1975 (which had limited wage and salary increases for 1976 to $£ 6$ per week), unit labor cost increases were brought down from 32.6 per cent in 1975 to I 2.7 per cent and hence below the current level of price inflation in 1976 . Only in Sweden did the unions still pursue an aggressive wage policy, while the Bourgeois coalition government, new in office after more than forty years of Social Democratic rule, was doing everything in its power to defend full employment.

After another two years, in 1978 , policy coordination had improved in West Germany and Sweden, and deteriorated again in Great Britain. With inflation below 3 per cent, and with the help of considerable American pressure at the Bonn Summit of 1978 (Putnam and Bayne, 1984), Chancellor Schmidt was finally able to persuade the Bundesbank of the wisdom and feasibility of a substantial fiscal and monetary reflation of domestic demand. As the unions continued on their course of wage moderation, employment in West Germany profited until 1980 from the country's assumption of the 'locomotive' role. In Sweden, the unions now 
also accepted the need for wage moderation, even though unemployment was actually falling. By contrast, the British Labour government, in an effort to defend the pound against devaluation and to push down inflation that was still above I 5 per cent, had switched to a strategy of (moderate) fiscal and monetary restraint in spite of comparatively high levels of unemployment. Inflation finally dipped below 9 per cent in 1978 , but now the unions were no longer able to uphold their part of the Social Contract. The crippling strikes of the Winter of Discontent and the high wage settlements that ended it pushed inflation up again and prepared the ground for Margaret Thatcher's election victory in the spring of 1979 .

By 1980 , therefore, the new British government was practicing a brand of monetarist restraint that was not moderate at all, while the unions initially continued the aggressive wage drive that had led to the defeat of the Labour government. As a consequence, inflation returned to high levels while unemployment began to rise steeply. In the other three countries, Keynesian concertation continued as before, even as the international economic and monetary environment was again worsening under the double impact of the second oil crisis and of the American conversion to monetarism.

But by 1982 the changes in the international environment had worked their way through the policy-making processes of all four countries. Monetary policy became restrictive everywhere, and even Austria and Sweden, which were still or again governed by Social Democrats, struggled to reduce fiscal deficits under the compulsion of escalating interest rates in the international financial markets. At the same time, the unions in all four countries, either out of insight or under the compulsion of rapidly rising unemployment, not only moderated their wage claims but accepted significant real-wage losses. Thus, the variance among the macro-economic strategies of European countries had now all but disappeared. ${ }^{4}$

\section{The Perspectives of Macro-Economic Actors}

In the I 970 , countries still had a choice among macro-economic strategies with significantly different outcomes. So why were not all of them able to achieve, and maintain, the optimal concertation of fiscal and monetary reflation and union wage moderation that could have defended full employment and price stability at the same time? The problem was not primarily a cognitive one. After some initial misjudgments of the nature of the crisis, the double threat of cost-push inflation and demand-gap unemployment and an economically optimal policy response were well understood in all four countries. Policy-makers were also not yet inhibited by the notion that demand reflation might be entirely without effect upon 
the real economy, or that wages ought to be settled entirely by the laws of supply and demand in the market. Collective bargaining was effective in all four countries, and wages were understood as a political price whose determination could also be influenced within limits by considerations of macro-economic policy. But it was also understood, explicitly in Britain as part of a pre-election agreement between the TUC and the Labour Party (Crouch, 1982; Bornstein and Gourevitch, I984), and implicitly in the other three countries, that cooperation could not be compelled. The record of statutory wage and price controls in the late ig6os and early 1970 in Britain and in the United States, had been so negative (Frye and Gordon, 198 I) that voluntary wage restraint was the only option seriously considered in the four countries (Flanagan, Soskice, and Ulman, 1983).

If the economics of the problem were so essentially simple and reasonably well-understood by policy makers, why wasn't the optimal strategy practiced everywhere throughout the whole period? The reason, I suggest, lies in the inevitable discrepancy between the perspective of macroeconomic theory on the one hand, and the action perspectives of those corporate actors (Coleman, 1974) who are actually involved in macroeconomic policy choices. Each of them pursues its own versions of the collective interest, and these are influenced not only by differing politicoeconomic ideologies, but also by the perceptions associated with their specific functional roles ('you stand where you sit') and by self-interested concerns with organizational survival and growth, re-election, and career advancement. As a heroic simplification, it may suffice to distinguish only three sets of such actors - elected governments, central banks, and labor unions ${ }^{5}$ - in an attempt to explain macro-economic outcomes in the $1970 \mathrm{~s}$.

Closest to the view implied by macro-economic analysis is the perspective of elected governments, which are held politically accountable for both inflation and unemployment, as well as for tax increases, unbalanced budgets, balance-of-payments crises and devaluations of the currency. Thus the government view of policy choices and outcomes is likely to correspond to the analysis present in Figure 5. Labor unions, upon whose cooperation the successful fight against stagflation critically depends, are likely to view the world from a different perspective, as in Figure 6. Although unemployment, or at least the threat of rising unemployment, must be of even greater importance to them than to governments, inflation is not one of their primary concerns. Instead, it is plausible to assume that they will be preoccupied with real wage increases whenever there is no threat of rising unemployment. Rising rates of inflation may cut into the real value of nominal wage settlements, but from a union perspective that insight is more likely to justify aggressive wage bargaining than wage moderation. Finally, it may be assumed that central banks, if they are sufficiently independent to have an orientation differing from 
Figure 6: Macro-Economic Coordination: The Union View

\begin{tabular}{|c|c|c|}
\hline & \multicolumn{2}{|c|}{ Wage Policy } \\
\hline Monetary Policy & moderate & aggressive \\
\hline expansionary & $\begin{array}{l}\text { real wages: low } \\
\text { unemployment: low }\end{array}$ & $\begin{array}{l}\text { real wages: moderate } \\
\text { unemployment: low }\end{array}$ \\
\hline restrictive & $\begin{array}{l}\text { real wages: moderate } \\
\text { unemployment: high }\end{array}$ & $\begin{array}{l}\text { real wages: high } \\
\text { unemployment: very high }\end{array}$ \\
\hline
\end{tabular}

that of the elected government, will tend toward a professional perspective that primarily emphasizes price stability. In addition, they are likely to be concerned with the level of capital incomes, influenced by both policy variables: Wage moderation increases profits, and high interest rates increase income from monetary assets. Their decline could trigger a sequence of capital outflows, devaluation and domestic inflation. Figure 7 .

\section{Two Games of Macro-Economic Coordination}

Macro-economic policy outcomes are not produced by a single, unified actor but by a plurality of corporate actors whose strategies are not automatically coordinated by reference to a common goal or utility function. Furthermore, their choices are strategically interdependent in the sense that, for all of them, the achievement of their own preferred bundles of outcomes is perceived as the joint product of the actions of all participants. If these conditions are granted, it is reasonable to expect that a game-theoretical form of presentation will help to simplify and clarify further analysis. The first task, then, is the construction of one or more payoff matrices which accurately represent both, the perceived economic outcomes associated with any combination of strategic choices, and the valuation of these outcomes by the respective players.

\section{FiguRE 7: Macro-Economic Coordination: The Central Bank View}

Fiscal and

Monetary Policy

expansionary

restrictive

\section{Wage Policy}

moderate

aggressive

\begin{tabular}{|l|l|}
\hline $\begin{array}{l}\text { inflation: moderate } \\
\text { capital incomes: } \\
\text { moderate }\end{array}$ & $\begin{array}{l}\text { inflation: very high } \\
\text { capital incomes: } \\
\text { low }\end{array}$ \\
\hline $\begin{array}{l}\text { inflation: low } \\
\text { capital incomes: } \\
\text { very high }\end{array}$ & $\begin{array}{l}\text { inflation: high } \\
\text { capital incomes: } \\
\text { moderate }\end{array}$ \\
\hline
\end{tabular}


On the basis of the economic analysis summarized in Figures 5, 6 and 7 above, the rank order of preferences is relatively easy to derive for unions and central banks. By and large, the goals of central banks are fully compatible with one another, so that they will consistently prefer less inflation and higher capital incomes. By comparison, union preferences are conditional, but still unambiguous. Under conditions of full employment, they will prefer higher real wage increases, but if unemployment is rising, their foremost concern must be to save the jobs of their members. Elected governments, however, are faced with a trade-off between inflation and unemployment. They would prefer to avoid both problems, but if they cannot do so, they have no obvious once-and-for-all ranking of the possible mixes of outcomes.

In order to simplify, the basic ambivalence of government preferences will be represented by two distinct games of macro-economic coordination, labelled 'Keynesian' and 'monetarist.' Both are played between the government and the unions. ${ }^{6}$ The possible strategies of both sides (expansionary or restrictive fiscal and monetary policy, moderate or aggressive wage policy) are the same in both games, and so are the real-world consequences associated with these strategies. The two games differ only in the assumed valuation of these consequences by the composite player government.

In the Keynesian game, which was in fact played in almost all Western countries after 1973, the government considers unemployment as the most serious problem and treats inflation as a secondary but still important concern (Figure 8). Thus, the government would clearly prefer to achieve the macro-economically optimal concerted strategy of fiscal and monetary reflation and union wage restraint in cell $\mathrm{I}$ of the diagram. The worst case for a Keynesian government is the combination of demand deflation and aggressive union wage policy as in cell 4 , which would lead

Figure 8: The Keynesian Game of Macro-Economic Coordination (Preferences of players rank ordered I to 4 )

UNIONS

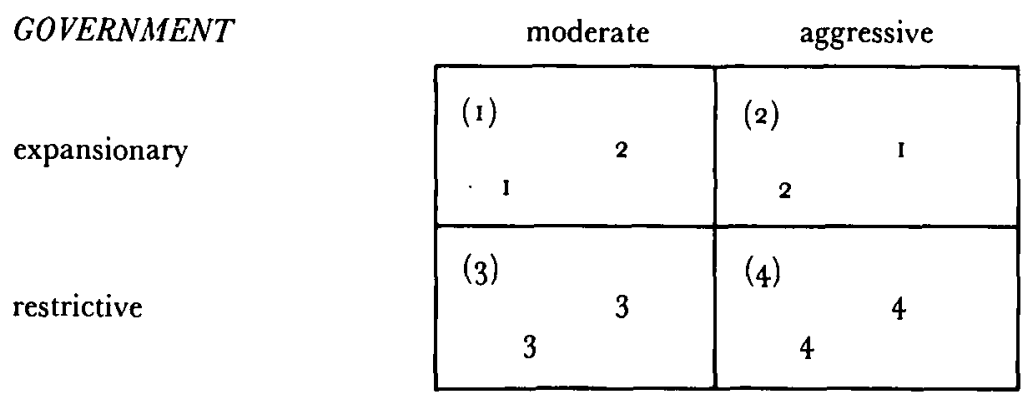


to very high unemployment and high inflation. The remaining two cases are of intermediate attractiveness. Their ordering depends on the relative importance of the concern about inflation.

From a union point of view, however, the government's optimum outcome (cell I) would be only the second best solution. As long as full employment is in fact maintained, it is in their immediate self-interest to shift to an aggressive wage policy in order to achieve the best outcome with low unemployment and higher real wages (cell 2). That this outcome is also associated with rising inflation may be an unfortunate side effect for the unions, while it must be a major political concern. Nevertheless, within the Keynesian game, the government could not now switch to a deflationary strategy unless it was willing to accept its own worst-case outcome with very high rates of unemployment (cell 4 ).

The Keynesian game, however, was not the only one that could be played. If either the central bank was able to impose its own preferences, or if the government was politically able and willing to treat inflation as the paramount problem, and to tolerate high levels of unemployment, the character of the coordination game would change (Figure 9). Now the government would most prefer a combination of very low rates of inflation and moderately high unemployment (cell 3), while cell 2 with very high inflation and low unemployment would become its worst-case outcome.

But if the government is willing to play the monetarist game, the options of the unions deteriorate dramatically. If they continue with an aggressive wage policy, as British unions did for a while after Margaret Thatcher's victory in 1979, they will end up in their own worst-case situation (cell 4), in which profit-gap unemployment caused by excessive wage increases is added to the demand-gap unemployment created by government policy. Thus, it is now in their self-interest to shift to wage restraint in order to avoid, or at least reduce further job losses and to improve their expected outcome from the worst case to second-worst (cell

\section{Figure 9: The Monetarist Game of Macro-Economic Coordination}

UNIONS

\begin{tabular}{|c|c|c|c|c|}
\hline GOVERNMENT & \multicolumn{2}{|c|}{ moderate } & \multicolumn{2}{|c|}{ aggressive } \\
\hline expansionary & (I) & 2 & $\begin{array}{l}\text { (2) } \\
4 \\
4\end{array}$ & I \\
\hline restrictive & (3) & 3 & (4) & 4 \\
\hline
\end{tabular}


3). For a monetarist government, however, this would be the best outcome from which it would have no reason to depart.

As the government has a dominant strategy in both games - expansion in the Keynesian, deflation in the monetarist case - both have a gametheoretical equilibrium in which neither side can improve its outcome by a unilateral change of strategy (Rapoport, Guyer, and Gordon, 1976: 18). It is in both cases defined by the unions' self-interested response to the government's strategy. Yet the underlying power relations are entirely different. In the Keynesian game, the unions are powerful because of the government's commitment to full employment, but they are entirely powerless when confronted with a monetarist strategy. By exploiting the former they may achieve their best short-term outcome, while they are forced to collaborate with the latter in order to avoid their worst-case outcome. ${ }^{7}$ At least in the economic environment of the 1970 , union power was very much a function of government strategy.

\section{The Choice of Coordination Games}

An explanation of economic outcomes in the rg7os thus needs to focus on the choice between the Keynesian and monetarist games that could have been played. In three of the four countries, that choice was formally exercised by elected governments. In West Germany, by contrast, the government's fiscal response to the onset of the crisis (which was as expansionary as that of the other countries) was largely neutralized by the tight-money policy of the central bank. Thus, the explanation for the defacto monetarism of West German economic policy in $1974 / 75$ is primarily to be found in the exceptional degree of institutional autonomy enjoyed by the Bundesbank (Woolley, 1985; Kloten, Ketterer, and Vollmer, 1985 ) and in the tactical brilliance with which it executed its shift to monetarism without risking an open political conflict with the government and the unions (Scharpf, 1987b: $165^{-1} 77$ ). When Keynesianism was practiced thereafter in West Germany, it was on probation and likely to be revoked at the first sign of rising inflation.

If we put the German case to one side, what factors can then explain the choice of games in the other three countries? In the literature, there are essentially two competing strands of theory dealing with the issue. From a 'class politics' perspective, what game is being played depends essentially on the class orientation of the party in power (Hibbs, 1977; r 982; Fiorina, 1978; Tufte, 1978) and on the 'power resources' of a labor movement favoring the ascendancy of labor-oriented parties (Korpi, 1983; EspingAndersen, 1985). On the other hand the theory of political business cycles (Nordhaus, 1975; McRae, 1977; Frey and Schneider, 1978; 1979; Peel, I 982 ; Lowery, 1985) emphasizes the anticipation of voter reactions by all 
governments, regardless of their party affiliations. ${ }^{8}$ Assuming that voters will respond more negatively to unemployment than to inflation, the theory predicts cyclical changes between Keynesian full-employment policy before, and monetarist anti-inflation policy after, general elections.

Applied in isolation, the power of both models to explain economic policy outcomes seems less than overwhelming, ${ }^{9}$ which is not much of a surprise, as both theories tend to focus on the motives of economic policy makers, and to ignore the conditions under which the preferences of governments can, or cannot, be translated into effective policy. Nevertheless it is promising to combine these hypotheses with the game theoretical model of macro-economic coordination developed above. The connection could be provided by the notion of a linkage between separate games played by one player against different opponents (Kelley, r 984; Denzau, Riker, and Shepsle, 1985; Shepsle, 1986; Putnam, 1986). In the first coordination game, the outcomes of macro-economic policy are jointly determined by the government and the unions, while in the second 'politics' game the government responds to its anticipation of positive or negative voter reactions to these outcomes. ${ }^{10}$

Different groups of voters will respond differently to macro-economic strategies. Simplifying again, one may lump these various groups into three socio-economic strata (Figure Io). The first stratum is without property and depends for its livelihood on relatively insecure jobs in the secondary labor market (Piore, 1979) and on government transfers. The

Fig U R E I0: Class Bases of Keynesian and Monetarist Strategies

Beneficiaries of Monetarism

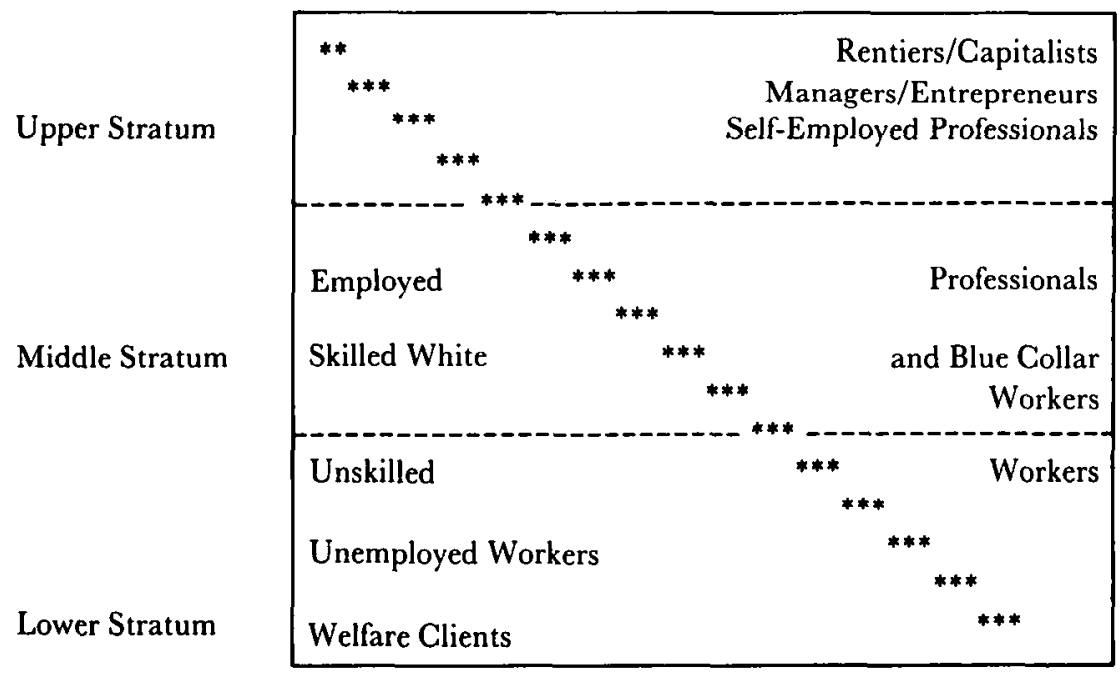

Beneficiaries of Keynesianism 
second stratum of skilled blue and white collar workers and professionals derives its income from more secure jobs in the primary labor market, and also from substantial property holdings (Miegel, I98I). The third stratum of self-employed professionals, managers, entrepreneurs, and rentiers depends primarily on profits and the returns of real and financial assets and is not directly affected by the labor market.

If these assumptions are granted, it is plausible that voters in the lower stratum have most to fear from a monetarist strategy associated with high unemployment and cutbacks in welfare spending, and that voters in the upper stratum would respond negatively to a Keynesian strategy associated with rising inflation, declining real interest rates and aggressive union wage demands. By contrast, voters in the middle stratum would have reason to be more ambivalent in their preferences. Their jobs are more secure than those in the lower stratum, but if unemployment rises and companies fail, they may feel even more threatened because they are likely to fall so much deeper. On the other hand, although these middle voters may even profit from inflation as home owners and debtors, they are likely to respond negatively to the disruption of established expectations associated with rapidly rising prices.

In addition, we need to introduce a set of assumptions about how governments might differ in their dependence on the electorate. Simplifying again, the model presupposes that the choices of the government are exercised by one of two competing parties, or coalitions of parties, with contrasting class bases of political support." Bourgeois parties appeal primarily to voters in the upper socio-economic stratum, while Labor parties have their electoral stronghold in the lower stratum. Each government identifies ideologically with the interests of its core clientele and favors macro-economic strategies that serve these interests. But it also will try to select policies that assure its re-election. If policies do not serve the interests of its core clientele, the model assumes that the government will lose some of its support, and will not be able to attract votes from the core clientele of the opposition. If that were all there is to the politics game, Labor governments would (under the economic conditions of the I970s) always have pursued Keynesian strategies, and Bourgeois governments would always have chosen to play the monetarist game.

But each government will be defeated if it loses the volatile support of the middle stratum of voters. As they are potentially concerned with both unemployment and inflation, their choices depend not on a general preference for either Keynesian or monetarist strategies but on specific economic circumstances and perceived consequences for their own interests. In general, it is reasonable to assume that middle voters will respond positively to a situation in which both, inflation and unemployment are avoided, and that they will respond negatively to a combination of high 
inflation plus high unemployment. When unemployment is low and inflation high, however, their response is likely to be asymmetrical. Whereas a shift from a Labor government to the Bourgeois opposition is plausible as a protest against high rates of inflation, the reverse shift is less probable if middle voters assume that under a Labor government inflation could only get worse.

Even more difficult to predict is the response of middle voters to the combination of low inflation and high unemployment. If inflation and unemployment were perceived as symmetrical, one might now expect a negative response, with perhaps a somewhat greater tolerance for Labor governments, on the hypothesis that they would be more motivated to work for a return to full employment. This response is indeed plausible when unemployment is a relatively new phenomenon. But once unemployment has persisted for some time, its political implications are likely to change.

While inflation is, by and large, perceived as a collective evil that irritates even those whose incomes keep up with prices, that is not generally true of unemployment. It is only the threat of mass joblessness, especially when it is experienced for the first time after almost two decades of full employment, that approximates a collective evil. Once unemployment has in fact risen, voters will realize that only a minority of the labor force is in fact affected, and it is also fairly obvious who is likely to be in that minority. For those who are not (and that is the overwhelming majority of the middle voters), unemployment is at best an altruistic problem, whose salience depends entirely on the 'moral climate' of the country ${ }^{12}$ and of the times, it is not a problem of their economic selfinterest. Thus, if we continue to assume self-interested voting among the middle layer of the electorate, we would predict support for Bourgeois as well as for Labor governments under conditions of low inflation and long-term unemployment.

With this we are now able to return to the linkage between the macroeconomic coordination game and the politics game. One way to present it is in the form of 'nested' games, where the outer frame is provided by the coordination game, which effectively determines the various combinations of inflation and unemployment to which the different strata of the electorate may respond in the politics game. As these will respond differently to governments of different political persuasion, each cell of the coordination game will contain two variants of the politics game, one for Labor and one for Bourgeois governments (Figure II).

Cell $I$ of the coordination game (obtained through a combination of Keynesian reflation and union wage restraint) did provide the optimal economic environment for the politics game from the perspective of a Labor government. The interests of its core clientele and its own political 
244 Fritz W. Scharpf

Figure I I: Voter Responses to Coordination Game Outcomes

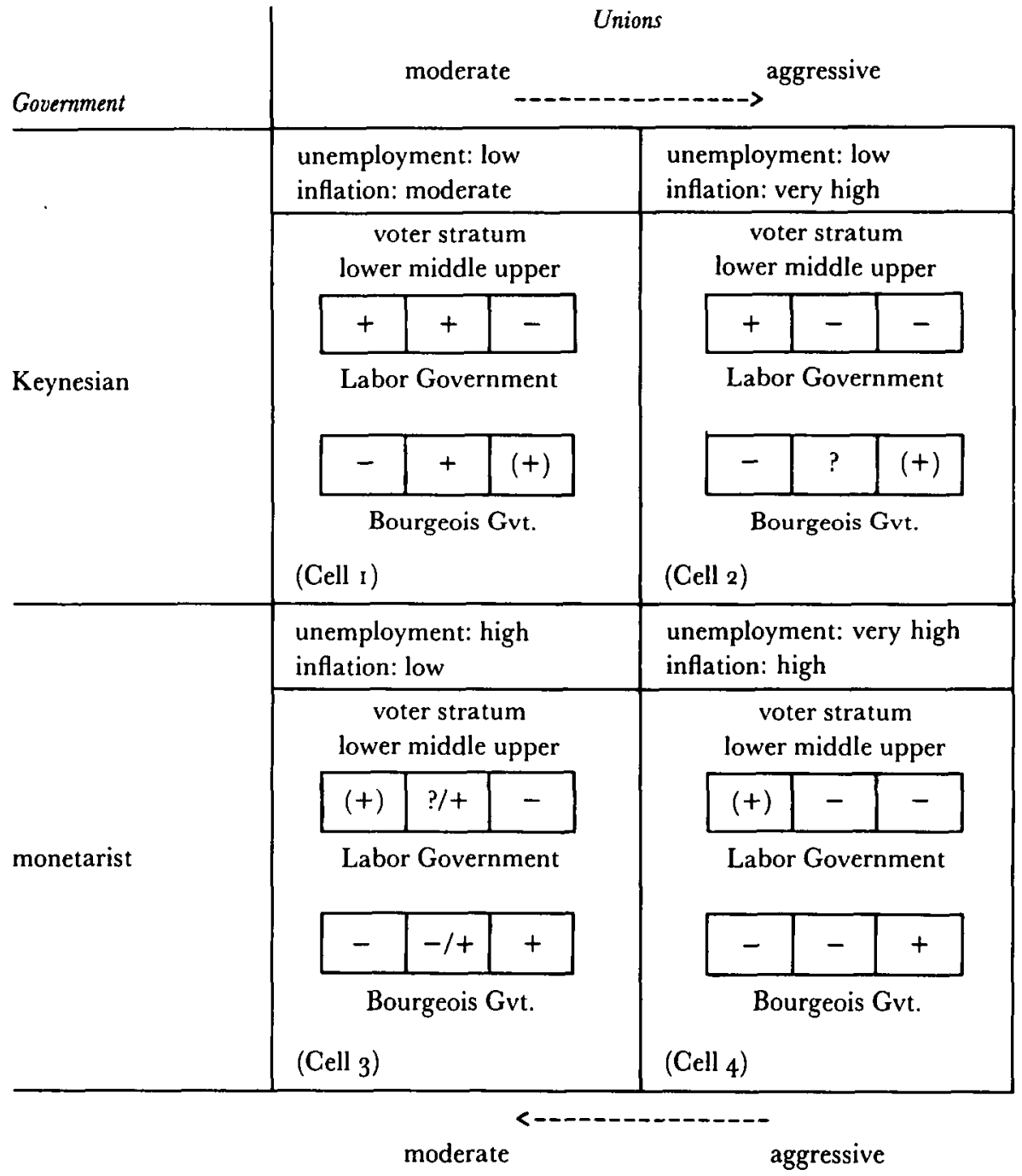

preferences were satisfied, and middle voters had no reason to defect. For a Bourgeois government, however, the same situation was less attractive since its own ideological preferences as well as the interests of its core clientele could not be satisfied by a Keynesian strategy. But as upper-stratum voters could not benefit from defecting to the Labor opposition, the government was still politically secure, and it could not improve its position by switching to a monetarist strategy as long as middle voters would still respond negatively to a rise of unemployment.

But if a union wage offensive shifted the Keynesian game into cell 2, as was likely under the assumptions introduced above, a Labor govermment 
would become extremely vulnerable in the politics game. While its core clientele would be satisfied, middle voters would respond negatively to the rapid increase of inflation and the Bourgeois opposition would present a highly credible alternative. Thus, if the government could not persuade the unions to shift back to wage moderation as in cell $I$, it was faced with two equally unattractive political options. It could choose to stick to its Keynesian guns, even if that meant almost certain electoral defeat, or it could gamble on a switch to monetarism, whose short-run effect would be the worst-case outcome of cell 4 , in the hope that the unions might then move toward wage restraint quickly enough to permit the government to reach the relatively safe haven of cell 3 before the next election. If a Bourgeois govermment found itself in the same economic situation of cell 2 its political survival would be less in danger, as middle voters could not expect a more vigorous anti-inflation strategy from the Labor opposition. Given the political risks associated with a switch to monetarism and an initial massive increase of unemployment (cell 4$),{ }^{13}$ a Bourgeois government might well prefer to continue the Keynesian game even in the absence of union wage restraint, and in doing so, its chances of political survival might be better than those of a Labor government.

The economic environment of cell 4 , with very high unemployment and still high rates of inflation, was politically viable for neither party. Perhaps a Labor government might do marginally better if the middle voters had reason to fear that a shift to the Bourgeois opposition could only make unemployment still worse. On the other hand, its own core clientele would suffer the most, while a Bourgeois government would at least begin to satisfy the interests of its upper-class clientele and would profit from their improving morale. Nevertheless, it is plausible to assume that either government would lose if elections were held during a period in which the economy found itself in cell 4 . But the coordination game was unlikely to remain there for long. If the monetarist game continued, the unions were forced by rising unemployment to moderate their wage claims. Thus, if governments managed to hang on long enough for this shift to become economically effective and politically salient, they would face more attractive prospects.

$\mathrm{Cell}_{3}$ is Janus faced. Its political implications are entirely different, depending upon whether it was entered from cell I or from cell 4 . In the first case, the political response would have been negative, as middle voters would be confronted for the first time with a significant rise of unemployment under conditions where there was not even much concern about inflation to justify the switch to monetarism. Unlike independent central banks, therefore, rational governments, Labor or Bourgeois would not shift to the monetarist game as long as they found themselves in cell $\mathrm{I}$. When cell 3 is entered from cell 4 , however, the politics game is of an 
entirely different character. Now the return to union wage restraint would help to reduce inflation visibly, and as business profits improved, unemployment would at least be stabilized and might even decline somewhat. As a consequence, joblessness would no longer appear as a personal threat to voters in the middle stratum. Under these conditions, cell .3 would become the political optimum for a Bourgeois govermment. Its own core clientele is pleased by the economic effects of the monetarist strategy, and the support of middle voters initially assured by favorable comparisons to the preceding period. If it is plausible to blame a predecessor Labor government for its initial rise, the political salience of continuing unemployment would be greatly reduced, ${ }^{14}$ and after a while dissonancereducing psychological mechanisms would blunt its moral salience as well. For a Labor government, by contrast, the situation is less comfortable. Although the unconcern of middle voters might assure its short-term political survival, continuing unemployment would hurt and demoralize its own core clientele. Thus, the government would be under strong political pressure to move back to a Keynesian full-employment strategy (cell I). If it did so, however, it was now uncertain of the continuing support of the middle stratum, whose sensitivity to inflation must have increased as they lost their fear of unemployment. At the least, a Labor government that returned to Keynesianism after a monetarist interlude would be vulnerable to be defeated as soon as inflation would rise again.

\section{How and When Did Corporatism Matter?}

The model is now sufficiently complex and realistic to be plausibly applied to the historical experience of macro-economic choices in the four countries between 1974 and 1982 . What we are now able to add to the economic analysis presented above is an explanation of government choices between Keynesian and monetarist strategies. It is derived from the logic of the 'politics' games which are played within each of the cells of the outer coordination game (Figure 12). The linkage between these games is established by the fact that the government is a player in both, and by the assumption that the government's moves in the coordination game are determined by its prospects of winning or losing in the politics game. Hence, the model would predict that governments will try to reach, or remain in coordination cells in which they are politically secure, and that they will try to avoid, or escape from, cells in which they are politically vulnerable. Voters are assumed to respond non-strategically to a given economic environment, and union moves in the coordination game are also assumed, for the time being, to be solely determined by their short-term economic self-interest. 
Figure 12: Historical Sequences of Coordination and Politics Games

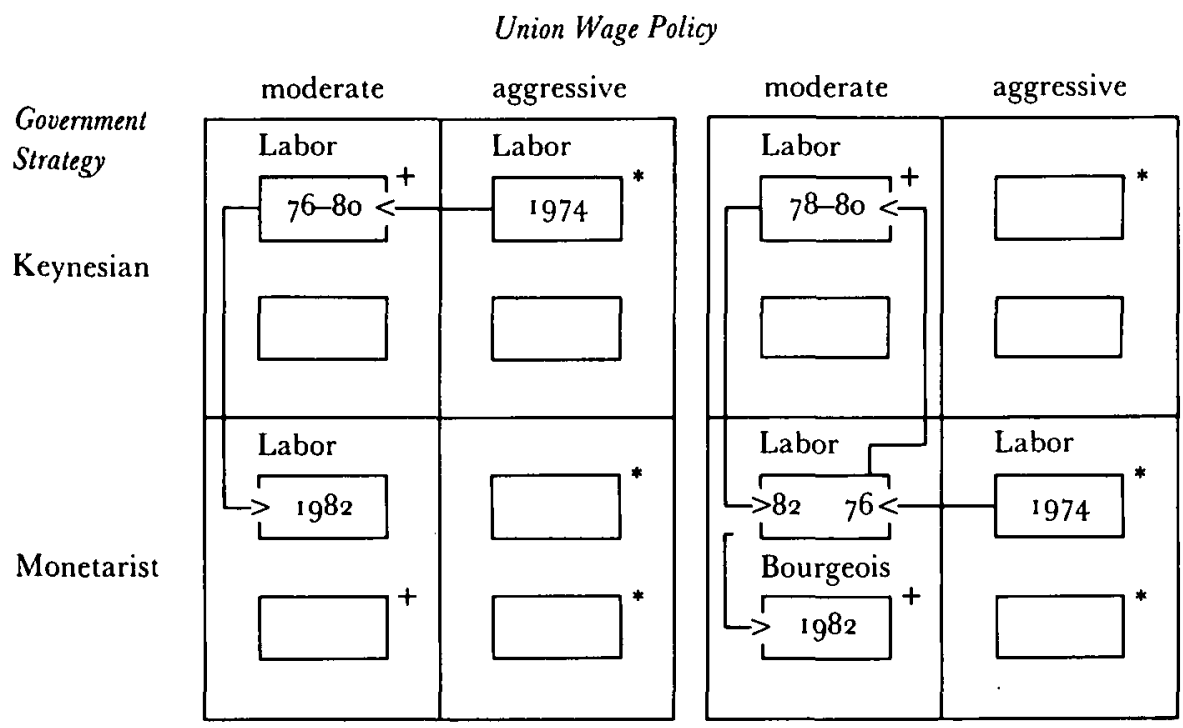

Austria

FR Germany

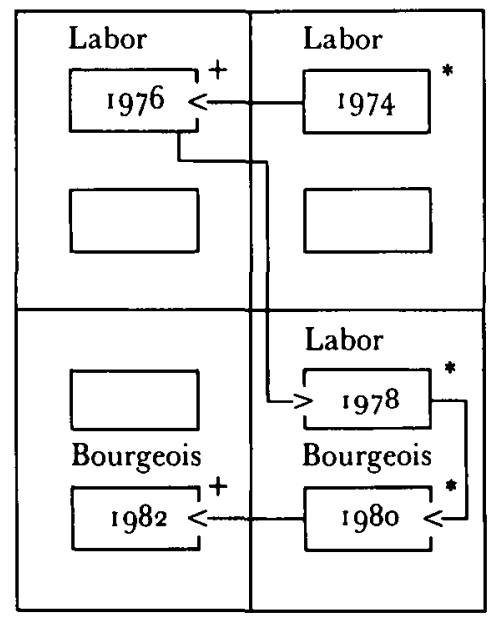

Great Britain

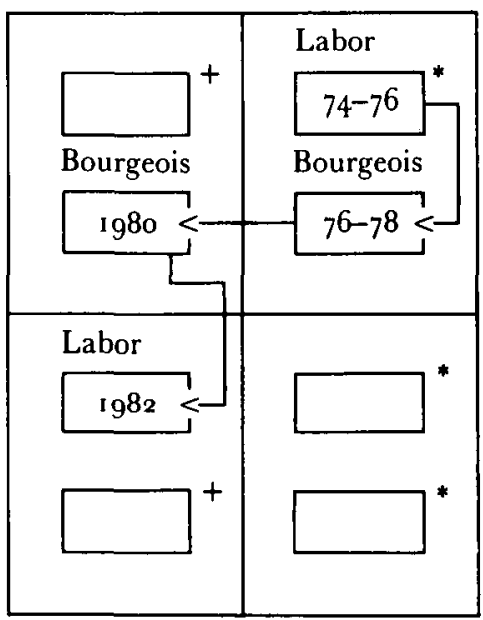

Sweden

$*$ = politically vulnerable position

$+=$ politically secure position

If we now apply this radically simplified 'rational-choice' model of macro-economic policy making to the actual policy experiences of the four countries during the period when they still had a choice between Keynesian and monetarist strategies, i.e. before the American conversion 
to monetarism, the model appears to fit quite well in some, but not in all instances.

At the beginning of the crisis in I 974 , all four countries were governed by Labor parties, and all four governments found themselves in macroeconomic positions which were vulnerable in the politics game. In Austria, Britain and Sweden the governments were able to assure full employment while the unions obtained inflationary wage settlements. In Germany, by contrast, the central bank enforced a tight money policy that limited but could not avoid the rise of inflation, and caused extremely high job losses. The model would predict that if these situations continued until the next general elections, ${ }^{15}$ all four governments would be politically vulnerable. Hence all had an interest in moving away from their uncomfortable positions. For this, however, they depended on the unions, as no government could have directly attained a more secure political position, solely by the exercise of its own economic policy options.

By I 976 , only one country, Sweden, had not changed its position within the coordination game - and the Swedish Social Democrats were indeed defeated by a Bourgeois coalition in the fall of $1976 .{ }^{16}$ In the other three countries the unions had helped to improve the government's political prospects by a move to wage moderation. But only in one country, Germany, can this move be explained within the present model as a selfinterested response to rising unemployment. In Austria and Britain, institutional factors not yet discussed must be drawn upon to explain the unions' willingness to shift to a pattern of Keynesian concertation which, in terms of short-term economic payoffs, was only the second-best solution which they could obtain.

By 1978 , Swedish unions had also shifted to wage moderation while the Bourgeois government remained firmly committed to full employment. The same was now true in Germany where the federal government was able to shift toward a full employment strategy after inflation was more or less under control. Thus, Austria, Sweden and West Germany were now (and until 1980) following a course of Keynesian concertation which was politically optimal for Labor governments, and at least politically viable for the Swedish Bourgeois coalition, but which depended upon union wage restraint not yet explained within the model. In Britain, by contrast, both the government and the unions had departed from Keynesian concertation by 1978 for reasons which may be plausibly interpreted within our model. The government had responded to persistent inflation with a shift to monetarism, hoping to push down prices without a dramatic increase of unemployment, and thus to reach the relatively safe haven of cell 3 . At the same time, the unions were aiming at cell 2 when they resumed their wage offensive in order to improve the real-wage position of their members after two years of extreme wage restraint. As a 
consequence of both moves, they found themselves in cell 4 , which was economically least attractive for the unions and politically non-viable for the Labor government in the 1979 general election.

Later developments also seem to conform well to the model: After their victory in 1979, Margaret Thatcher's Conservatives had sufficient time to wait for the unions to return to wage moderation (shifting the game to cell 3) under the compulsion of very high unemployment. When that point had been reached by 1982 , the Bourgeois government was politically secure. The German Social Democrats were ousted not by the voters, but by their Liberal coalition partners in the fall of 1982 . Yet their position had also become electorally vulnerable as unemployment was rapidly increasing after another heavy dose of monetarism applied by the Bundesbank. As a consequence, the new Christian-Liberal government was able to win comfortable majorities in subsequent elections. In Sweden, on the other hand, the Bourgeois government did not survive the externally imposed shift to monetarism, after which unemployment had begun to creep up by 1982, but the Social Democrats' subsequent hold on power remained tenuous, even though the devaluation of the kronor kept Swedish unemployment at comparatively very low levels. The same is by and large true of Austria, where the unions have been even more cooperative than in Sweden, but where the commitment to fixed exchange rates against the Deutsche Mark precluded devaluation, so that the rise of unemployment did more to undercut Labor support.

Thus, the model seems to be reasonably successful in explaining the policy choices of elected governments in all four countries. It is also sucessful in explaining union responses to a monetarist government strategy which allowed unemployment to rise. If governments practiced Keynesian reflation, however, unions in all countries sometimes conformed to the model by adopting an aggressive wage policy, and sometimes they were able and willing to exercise wage restraint even though full employment was maintained. It was this choice of unions, as yet unexplained, which ultimately determined government preferences for Keynesian or monetarist strategies.

There were in the 1970 and early 1980 s two positions within the coordination game at which a government might be secure within the politics game (cell i for Labor, and cell 3 for Bourgeois governments), and a number of positions at which governments were politically vulnerable. But the chances of survival were unevenly distributed. While Bourgeois governments, once they had reached their politically preferred position, could count on the self-interested collaboration of the unions in the coordination game, the same was not true of the optimal position of Labor governments. It represented a political equilibrium but not a coordination equilibrium. If unions would follow their own short-term preferences 
in the coordination game, Labor governments would find themselves in a politically untenable position (cell 2). If the government then looked only to its own political survival, it would be tempted into a desperate shift to monetarism which, even if it succeeded politically, would increase unemployment. If it failed, as it did in Britain, it would help to establish a Bourgeois government that was politically secure in spite of continuing high unemployment.

Thus, if both Labor governments and unions were to follow their shortterm institutional self-interests, the result would have been a sequence of unstable situations which could only come to an end in a Bourgeoismonetarist constellation that represented a stable equilibrium in the politics game as well as in the coordination game. From the perspective of the labor movement, however, that sequence was a disaster for Labor parties as well as for unions - and one that was easily anticipated. The question is, therefore, under which conditions the sequence could have been interrupted and reversed before the Bourgeois-monetarist equilibrium was established. What was required is clear enough: the unions would have to be willing and able to forego short-term wage gains in order to allow the government to reach cell i of the coordination game, where it was in its own political self-interest to defend full employment. That was the essence of the 'neo-corporatist Keynesian concertation' achieved in Austria between 1976 and 1980, in Britain between 1976 and 1978 , and in Sweden and West Germany between 1978 and 1980.

What was involved was not in the strict sense a question of 'political exchange' (Pizzorno, I978, Marin, I985). To the extent that a Labor government pursued full-employment strategies, it was acting out of selfinterest, and not as a reward for the unions. It had nothing else to offer them in return for wage moderation, and it could only warn them of its own impending political demise, not threaten it. What was in question, instead, was the unions' capacity of self-management (Elster, 1979; Schelling, I $9^{84}$ ), that is their ability to avoid both the temporal trap of favoring short-term over longer-term definitions of self-interest and the 'social trap' of favoring competitive sub-group interests over the collective interest of the union movement (Messick and McClelland, 1983).

In other words, an explanation of instances of successful Keynesian concertation must focus on departures from the action perspective of narrow and myopic self-interest that is presupposed in rational-choice models. With this we are now finally approaching the institutional explanations upon which political science studies of macro-economic performance have focused primarily (and with insufficient justification). Certain institutional arrangements will permit and perhaps encourage (but not compel) actors to take a more inclusive and longer-term perspective, and other institutional conditions will make it more difficult 
(but not impossible) to take a wider view. It is in this respect that neocorporatist institutions in general, and centralized and concentrated union organizations in particular, do seem to make a difference. Solidarity, as well as the ability to anticipate the future in present choices, is undercut by competition between individual unions, and it is facilitated (though not assured) by organizational concentration in the union movement and by the effective centralization of collective bargaining decisions.

In Britain, to begin with the most obvious case, the extreme fragmentation of union organization (the TUC alone still had over one hundred member unions in the I970s), and the decentralization of collective bargaining to the level of individual firms, plants, or even the shop floor within plants, created enormous competitive pressures within the union movement (Barnes and Reid, 1980). Negotiators in each of the small bargaining units tend to exploit fully the ability to pay of profitable firms and the bargaining strength of scarce skill groups, and they would suffer in inter-union competition if their own settlements were more moderate than those achieved elsewhere. Under such conditions, voluntary wage restraint, even if its economic or political benefit to the union movement as a whole were obvious, is a collective good whose attainment is highly vulnerable to free-riding.

By contrast, the free-rider problem is significantly reduced in the other three countries whose institutions, though quite different, conformed to a greater degree to the neo-corporatist model. In Austria and West Germany, the national union movements consist of no more than 16 or i 7 industrial unions that do not compete against each other. Collective bargaining is also quite centralized within each union, with effective decisions taken at the national level even if regional settlements may differ. Under such conditions, union negotiators must be concerned about job losses in weaker firms or regions, and they are less free to exploit pockets of local bargaining strength. They must, in other words, permanently work to achieve a collective or solidaristic definition of the selfinterest of divergent groups of workers in order to assure their own organizational survival (Streeck, I98I). An even more inclusive perspective is introduced by the formal role of the central union federation in collective bargaining in Sweden and Austria (Marin, 1982), and by the de facto wage leadership of the largest industrial unions in West Germany (Streeck, $1982 ; 1984$ ). In one way or another, therefore, a collective definition of the self-interest of the union movement could be worked into the normal processes of collective bargaining by large, 'encompassing' (Olson, 1982) organizations on the union side. At the same time, organizational centralization assured union leaders some limited freedom to pursue longer-term strategies even in the face of rank-and-file discon- 
tent, and it provided them with opportunities to present and defend more enlightened, longer-term definitions of union self-interest in internal discussions.

Austrian and German unions were able to practice wage restraint after 1975 in a spirit of business as usual that was hardly noticed by anybody outside of professional circles. In Britain, by contrast, the success of the Social Contract in 1976 and 1977 depended entirely on a most extraordinary exertion of political and moral pressure by government and top union leaders. Local bargaining units and shop stewards were browbeaten into compliance by a national campaign to 'give a year to Britain,' replete with appeals to the 'spirit of Dunkirk' and to the solidarity of the labor movement with an embattled Labour government. The emphasis was on short-term sacrifices, and the $\mathfrak{E 6}$ rule, which wrought havoc with jealously defended wage differentials, was chosen for its maximal moral appeal and for its high visibility, discouraging evasions.

The Swedish case is less clear-cut (Martin, 1984; 1986b). The number of unions is larger than in Austria or West Germany (about 25), and there is considerable wage competition between the blue-collar unions, organized by industry, and the white-collar unions, which are mainly organized by skill level. At the same time, however, the national federation of blue-collar unions and national cartels of white-collar unions have a larger role in collective bargaining than is true in the other countries. Yet there is also a good deal of wage drift generated by local wage rounds in the more profitable (or state owned) firms, which is then generalized to the whole economy by an ever denser network of compensation clauses in collective agreements. Nevertheless, whenever this was considered necessary, the Swedish labor movement was able to draw upon moral resources and an unspectacular but effective commitment to solidaristic values to constrain self-interested competition between individual bargaining units.

It seems plausible to ascribe the aggressive and the economically damaging Swedish wage rounds after 1975 not to a fundamental institutional incapacity, but perhaps to a temporary lapse of judgment and, after I 976 , to the fact the unions saw little need to assist the new Bourgeois government in its macro-economic management. After all, if that government had failed, the Social Democrats, rather than Thatcherite conservatives, would have returned to office. But when it became clear after 1978 that the Swedish economy was in fact suffering, union wage moderation was again forthcoming. The same was true, in spite of considerable tensions within the union movement, after 1982.

If and when the union movement as a whole had reason to consider wage restraint as its own best strategy, neo-corporatist institutional conditions facilitated that choice in Austria, West Germany, and Sweden. 
In Britain, their absence could be compensated for a time by extreme exertions of ideological pressure and moral leadership. But it was always clear that the Social Contract was not institutionally viable as a longerterm strategy, and that the inevitable return to free collective bargaining would again release the pent-up pressures of wage competition. The only question was whether the breakup had to occur under dramatic circumstances in 1978 , or whether a more sensitive management of governmentunion relations and better timing could have facilitated a more orderly retreat that might have allowed Callaghan to survive another general election.

Neo-corporatist institutions are of relevance to macro-economic policy only as long as the Keynesian game is being played. If the government shifts to a monetarist strategy, wage restraint (which is still required for its success) no longer depends on the organizational concentration of the union movement and on the centralization of collective-bargaining decisions. ${ }^{17}$ The reason is analytically straightforward. Job losses, unlike inflation, are primarily experienced not as a collective evil but as an individual risk whose avoidance is in the immediate self-interest of individual workers and hence not vulnerable to free-riding. As soon as unemployment is allowed to rise, therefore, the overriding interest in protecting existing jobs will motivate wage concessions not only by the union movement as a whole, but also at lower levels of collective bargaining. ${ }^{18}$ Under such conditions, there is no reason to assume that decentralized and fragmented union movements that are otherwise characterized by greater militancy (Cameron, 1984) should be any less 'docile' than highly centralized and disciplined corporatist unions are said to be (Panitch, 1979). It is thus entirely plausible, within the model developed here, that neo-corporatist institutions should explain a great deal of economic variance during the Keynesian I970s, and much less during the monetarist 1980 .

\section{NOTES}

1. In this paper, I concentrate on the explanation of macro-economic policy, which affects unemployment through its impact on the number of jobs offered in the economy. This is, of course, not the whole story. Governments did resort to a variety of other strategies to prevent, reduce, or conceal the rise of unemployment (Wilensky and Turner, 1987). Switzerland, for instance, relied almost entirely on the repatriation of foreign workers to compensate for very large job losses (Schmidt, 1985 ). Sweden on the other hand reduced potential unemployment by almost four percentage points between 1974 and 1978 through active labor market retraining and subsidized employment. West Germany combined both strategies with the early retirement of older workers to achieve a similar reduction of the labor supply (Scharpf, $1987 \mathrm{~b}: 279-293$ ).

2. In the 'monetarist' environment of the 1980 s, by contrast, wage restraint came to mean falling real wages or, at the least, reductions of real unit labor costs in order to increase the profitability of capital.

3. After the onset of the second oil crisis in 1979 , the United States, which before had facilitated worldwide expansionary strategies through its relatively loose fiscal and monetary policy, 
switched to a monetarist tight money policy which increased real long-term dollar interests from a low of -3 per cent at the beginning of 1980 to an average of +6 per cent in 1982 and a high of +8 per cent in $19^{8} 3$. Given the paramount role of the dollar in the international capital markets, all other industrial countries were also forced to reduce their money supply and to raise their interest rates (Funke, 1986). As a further consequence, national fiscal policy also became less effective as an instrument of expansion and much more expensive. Therefore, most Western European countries pursued restrictive fiscal and monetary policies after 1981 - and those that did not at first (Mitterrand's France, for instance) were soon compelled to follow suit in order to avoid massive outflows of capital and a dramatic devaluation of their currencies.

4. When the Social Democrats returned to power in Sweden in the fall of 1982 , they achieved a limited degree of demand reflation through the competitive devaluation of the kronor, a strategy which not all countries could have adopted.

5. In their collective-bargaining role, one might include employers' associations as macro-economic actors of marginal importance. Even though one may generally presume that the degree of their resistance to wage increases is determined by economic self-interest, it is at least conceivable that the relative toughness of their position may also be influenced by considerations including the state of the macro-cconomy. But it is not plausible to assume that business associations could be a player in a macro-economic inflation game modelled after the Prisoner's Dilemma, in which they choose between high and low price increases while the unions choose high or low wage increases (Maital and Benjamini, I979; Neck, 1985). Price-setting decisions (and investment decisions, for that matter), although of critical importance for the performance of the economy, are not the subject of collective choices in capitalist economies. The recent concern of social scientists with the organization of business interests (Streeck and Schmitter, 1985) should not obscure this important difference.

6. Even when the central bank is an autonomous player, it is not necessary to represent the constellation as a three-person game. As fiscal and monetary policy operate upon the same parameters of aggregate demand, any discrepancy between the two will affect the de facto choice of a single 'government' player.

7. In my view it is thus not correct to argue, as Peter Lange and Geoffrey Garrett (1985: 799-800, $817)$ have done, that wage restraint is rational for unions only as long as the government will guarantee economic growth and full employment. On the contrary: That is precisely the government with whom self-interested unions will find it most difficult to cooperate. Only a government that is willing to tolerate high unemployment may count upon their self-interested moderation.

8. Frey and Schneider ( $1978 ; 1979)$ combine both assumptions: In their model, governments will pursue their own ideological preferences until their popularity falls below a critical threshold at which their re-election is in danger.

9. The class orientation of political parties did indeed matter in the switch from Callaghan to Thatcher in Britain, or from Giscard to Mitterrand in France, but it does not explain the relative continuity of economic policy after changes of government in Sweden and in the United States in 1976 , or in West Germany in 1982 . Similarly, the theory of the political business cycle may perhaps explain German fiscal policy in 1980 , but the Austrian and Swedish governments seem to have continued their chosen course with little regard for the timing of elections, and the Carter administration did switch to a monetarist anti-inflation strategy in 1979 , which predictably increased US unemployment before the I980 elections.

10. It is perhaps necessary to emphasize that we are trying to explain not election outcomes but policy choices, and that we are dealing with the perceptions of policymakers. Elections are in fact won or lost over a multitude of issues, of which the course of the economy is not always the most salient one. Nevertheless it is reasonable to assume that risk-averse economic policymakers will anticipate the response of self-interested voters.

I1. The model could accommodate coalition governments with cross-cutting class orientations, but not the 'new politics' of non-class issues, movements and parties (peace, ecology, gender, life styles, ethnic, regional, etc.).

12. It is here that the 'power resource' theory is most persuasive. A powerful labor movement of the Scandinavian or Austrian type, with a strong presence in all societal institutions, including the mass media, may indeed exercise a degree of ideological hegemony that may at least postpone the shift to a neo-conservative lifeboat ethics and the egoistic redefinition of middle-stratum interests.

13. Here, the length of the electoral cycle and the closeness of the next general election is obviously important. Quite apart from other differences, the British five-year electoral cycle enhanced, and the Swedish three-year cycle reduced, the political feasibility of a switch to monetarism. 
14. A change of government thus changes the 'framing' (Kahneman and Tversky, 1984) of the base line from which political success and failure are being measured.

1 15. As the seriousness of the economic crisis did not become obvious until the winter of $1974 / 75$, the British elections in the fall of 1974 would not count as a deviation from the model.

16. It is perhaps fair to add that Swedish Social Democrats attribute the change of government more to the dispute over nuclear energy than to a deep dissatisfaction with their management of the economy.

17. There might actually be a reverse relationship: Under conditions of high unemployment, it would require a highly solidaristic labor movement to design and implement an aggressive wage campaign that, by further increasing unemployment in the short run, might help to defeat a Monetarist government at the next election. On that hypothesis, the union-busting thrust of recent industrial-relations legislation in Britain, while entirely counter-productive within a Keynesian frame of reference, may actually make party political sense.

18. It is still true, however, that fragmented industrial relations systems tend to generate more endogenous wage pressure than neo-corporatist ones. Even under conditions of high general unemployment, there will be firms that are doing well and skill groups that are in high demand, and these pockets of labor power will be exploited in fragmented systems. Thus, even though unemployment was much higher, the real wages of those who still had jobs rose more in Britain after 1980 than they did in Austria, Sweden, and West Germany.

\section{REFERENCES}

Barnes, Denis and Eileen Reid (1980) Governments and Trade Unions. The British Experience $196_{4}-1979$. London: Heinemann.

Berger, Suzanne, ed. (1981) Organizing Interests in Western Europe. Cambridge: Cambridge University Press.

Bornstein, Stephen and Peter Gourevitch ( $\left.\mathrm{r}_{9} 8_{4}\right)$ Unions in a Declining Economy: The Case of the British TUC. In Gourevitch et al. $13-88$.

Cameron, David R. ( 1978 ) The Expansion of the Public Economy: A Comparative Analysis. American Political Science Review 72: 1 243-1261.

Cameron, David R. (1984) Social Democracy, Corporatism, Labor Quiescence, and the Representation of Economic Interest in Advanced Capitalist Society. In Goldthorpe, ed. 143-1 78 .

Coleman, James S. (1974) Power and the Structure of Society. New York: W. W. Norton Co.

Crouch, Colin (1982) The Politics of Industrial Relations, London: Fontana Paperbacks, 2nd ed.

Crouch, Colin and Pizzorno, A., ed. (1978) The Resources of Class Conflict in Western Europe since 1968. London: Macmillan.

Denzau, Arthur, William Riker and Kenneth Shepsle ( g $^{8} 8_{5}$ ) Farquharson and Fenno: Sophisticated Voting and the Home Style. American Political Science Review 79: I I 7 - I 134.

Elster, Jon (1 979) Ulysses and the Sirens. Studies in Rationality and Irrationality. Cambridge: Cambridge University Press.

Esping-Andersen, Gösta (1985) Politics against Markets. The Social-Democratic Road to Power. Princeton: Princeton University Press.

Fiorina, Morris P. (1978) Economic Retrospective Voting in American National Elections: A Microanalysis. American Joumal of Political Science 1 I: $426-473$.

Flanagan, Robert J., David W. Soskice and Lloyd Ulman ( $19^{8} 3$ ) Unionism, Economic Stabilization and Incomes Policies: The European Experience. Washington, DC: Brookings.

Frey, Bruno S. and Friedrich Schneider (1 978) An Empirical Study of Politico-economic Interaction in the United States. Review of Economics and Statistics 60: $174-183$.

Frey, Bruno S. and Friedrich Schneider (1979) An Econometric Model with an Endogenous Government Sector. Public Choice 34: 29-43.

Frye, Jon and Robert J. Gordon (I98I) Government Intervention in the Inflation Process: The Econometrics of 'Self-Inflicted Wounds.' American Economic Review 7 1: 288-294.

Funke, Michael (1986) Nominalzinsen, Realzinsen und internationale Kapitalbewegungen. Wissenschaftszentrum Berlin: Discussion Paper IIM/LMP 86- 1 .

Garrett, Geoffrey and Peter Lange (1978) Performance in a Hostile World: Economic Growth in Capitalist Democracies, 1974-80. World Politics 38: 51 7-545.

Goldthorpe, J. H. ed. (1984) Order and Conflict in Contemporary Capitalism. Oxford. Clarendon Press.

Gourevitch, Peter ed. (1984) Unions and Economic Crisis: Britain, West Germany and Sweden. London: Allen and Unwin. 
Hall, Peter (1986) Governing the Economy. The Politics of State Intervention in Britain and France. London: Polity Press.

Hibbs, Douglas A. (1977) Political Parties and Macroeconomic Policy. American Political Science Review 71: $1467-1487$.

Kahneman, David and Amos Tversky (1984) Choice, Values, Frames. American Psychologist 39: 341-350.

Kelley, Harold H. ( 1984 ) The Theoretical Description of Interdependence by Means of Transition Lists. Joumal of Personality and Social Psychology 47: 956-982.

Kloten, Norbert, Karl-Heinz Ketterer and Rainer Vollmer (1985) West Germany's Stabilization Performance. In: Lindberg and Maier, eds. 353-402.

Korpi, Walter (1983) The Democratic Class Struggle. London: Routledge \& Kegan Paul.

Lange, Peter and Geoffrey Garrett ( 1985 ) The Politics of Growth: Strategic Interaction and Economic Performance in the Advanced Industrial Democracies, 1974-1980. Joumal of Politics 47: 792-827.

Lehmbruch, Gerhard and Schmitter, Philippe C., eds. (I982) Patterns of Corporatist Policy-Making, London: Sage.

Lindberg, Leọn N. and Maier, C. S., eds (1985) The Politics of Inflation and Economic Stagnation. Washington DC: Brookings Institution.

Lowery, David (1985) The Keynesian and Political Determinants of Unbalanced Budgets: US Fiscal Policy from Eisenhower to Reagan. American Joumal of Political Science 29: 428-460.

MacRae, C. Duncan (1977) A Political Model of the Business Cycle. Joumal of Political Economy 85: 239-263.

Maital, Shlomo and Yael Benjamini (rg79) Inflation as a Prisoner's Dilemma. Joumal of Post Keynesian Economics 2: $459-48$ I.

Malinvaud, Edmond (1977) The Theory of Unemployment Reconsidered. Oxford: Basil Blackwell.

Marin, Bernd (1982) Die Paritätische Kommission. Aufgeklärter Technokorporatismus in Österreich. Vienna: Internationale Publikationen.

Marin, Bernd ( 1985 ) Generalized Political Exchange: Preliminary Considerations. Florence: EUI Working Paper No. 85/1 go.

Martin, Andrew (1984) Trade Unions in Sweden: Strategic Responses to Change and Crisis. In: Gourevitch et al. $189-359$.

Martin, Andrew (I g86a) The Politics of Employment and Welfare: National Policies and International Interdependence. In: Banting, ed. I 57-240.

Martin, Andrew (1986b) The End of the 'Swedish Model?' Recent Developments in Swedish Industrial Relations MS, Center For European Studies, Harvard University.

Messick, David M. and Carol L. McClelland (1983) Social Traps and Temporal Traps. Personality and Social Psychology Bulletin 9: 105-1 10.

Miegel, Meinhard ( 198 I) Sicherheit im Alter. Plädoyer für die Weiterentwicklung des Rentensystems. Stuttgart: Bonn Aktuell.

Neck, Reinhard (I 985 ) Das österreichische System der Sozial- und Wirtschaftspartnerschaft aus politisch-ökonomischer Sicht. Journal für Sozialforschung 25: 375-403.

Nordhaus, William (1975) The Political Business Cycle. Review of Economic Studies 42: I69-1 90.

Olson, Mancur (1982) The Rise and Decline of Nations: Economic Growth, Stagfation, and Social Rigidities. New Haven: Yale University Press.

Paloheimo, Heikki ( 1984 ) Distributive Struggle, Corporatist Power Structures and Economic Policy of the 1970 s in Developed Capitalist Countries. In: Paloheimo, ed. $1-46$.

Paloheimo, Heikki, ed. $(1984)$ Politics in the Era of Corporatism and Planning. Tampere: The Finnish Political Science Association.

Panitch, Leo (1979) The Development of Corporatism in Liberal Democracies. In: Schmitter and Lehmbruch, eds. $119-146$.

Peel, David A. (1982) The Political Business Cycle - Have We Seen the End of it? Long Range Planning 15: 30-33.

Piore, Michael J., ed. (I979) Unemployment and Inflation. Institutionalist and Structuralist Views. White Plains, NY: M. E. Sharpe.

Pizzorno, Alessandro (1978) Political Exchange and Collective Identity in Industrial Conflict. In: Crouch and Pizzorno, eds. 277-298.

Przeworski, Adam and Henry Teune (1970) The Logic of Comparative Social Inquiry. New York: Wiley-Interscience.

Putnam, Robert D. ( 1986 ) The Logic of Two-Level Games: International Cooperation, and Western Summitry, 1975-1986. Ms. Department of Government, Harvard University. 
Putnam, Robert D. and Nicholas Bayne (1984) Hanging Together. The Seven-Power Summits. London: Heinemann.

Rapoport, Anatol, Melvin J. Guyer and David G. Gordon (1976) The $2 \times_{2}$ Game. Ann Arbor: University of Michigan Press.

Scharpf, Fritz W. (1981) The Political Economy of Inflation and Unemployment in Western Europe: An Outline. Wissenschaftszentrum Berlin: Discussion Paper IIM/LMP $81-21$.

Scharpf, Fritz W. (1984) Economic and Institutional Constraints of Full-Employment Strategies: Sweden, Austria and West Germany. In: Goldthorpe, ed. 257-290.

Scharpf, Fritz W. (1987b) Sozialdemokratische Krisenpolitik in Europa. Das 'Modell Deutschland' im Vergleich. Frankfurt: Campus.

Schelling, Thomas C. (1984) Choice and Consequence. Cambridge, MA: Harvard University Press.

Schmidt, Manfred G. (1982) Does Corporatism Matter? Economic Crisis, Politics and Rates of Unemployment in Capitalist Democracies in the 197os. In: Lehmbruch and Schmitter, eds. 237-258.

Schmidt, Manfred G. $\left(\mathrm{g}^{8} 8_{3}\right)$ The Welfare State and the Economy in Periods of Economic Crisis: A Comparative Study of Twenty-Three OECD Nations. European Joumal of Political Research i 1: 1-26.

Schmidt, Manfred G. (1985) Der Schweizerische Weg zur Vollbeschäftigung. Eine Bilanz der Beschäftigung, der Arbeislosigkeit und der Arbeitsmarktpolitik. Frankfurt: Campus.

Schmidt, Manfred G. (1986) Politische Bedingungen erfolgreicher Wirtschaftspolitik - Eine vergleichende Analyse westlicher Industrieländer. Joumal für Sozialforschung, 1986, Heft 3.

Schmitter, Philippe C. (1974) Still the Century of Corporatism? Review of Politics 36: 85-131.

Schmitter, Philippe C. ( $198 \mathrm{I}$ ) Interest Intermediation and Regime Governability in Contemporary Western Europe and North America. In: Berger, ed. 287-327.

Schmitter, Philippe C. and Lehmbruch, Gerhard, eds. (1979) Trends Toward Corporatist Intermediation. London: Sage Publications.

Shepsle, Kenneth A. ( 1986 ) Cooperation and Institutional Arrangements. Paper prepared for the Harvard Conference on International Regimes and Cooperation, February 13-15, 1986.

Streeck, Wolfgang (1981) Gewerkschaftliche Organisationsprobleme in der sozialstaatlichen Demokratie. Königstein: Athenäum.

Streeck, Wolfgang, (1982) Organizational Consequences of Neo-Corporatist Cooperation in West German Labor Unions. Lehmbruch and Schmitter, eds. 29-81.

Streeck, Wolfgang (1984) Neo-Corporatist Industrial Relations and the Economic Crisis in West Germany. Goldthorpe, ed. 29I-314.

Streeck, Wolfgang and Philippe C. Schmittcr ( 1985 ) Private Interest Government. Beyond Market and State. London: Sage.

Therborn, Göran (1986) Why Some Peoples Are More Unemployed Than Others. The Strange Paradox of Growth and Unemployment. London: Verso.

Tufte, Edward R. (1978) The Political Control of the Economy. Princeton: Princeton University Press.

Wcintraub, Sidney (1978) Capitalism's Inflation and Unemployment Crisis. Reading, MA: Addison-Wesley.

Wilensky, Harold L, and Lowell Turner (1987) Democratic Corporatism and Policy Linkages. The Interdependence of Industrial, Labor-Market, Incomes, and Social Policies in Eight Countries. Berkeley: Institute of International Studies.

Woolley, John T. (1985) Central Banks and Inflation. In: Lindberg and Maier, eds. 318-35I. 